[計測自動制 御 学 会論文集]

[ Vol.53, No.2, 188/197 (2017) ]

\title{
ビル内アトリウムの熱移動モデリングへのクープマンモード分解の適用-II 一大スケール流速場による移流—
}

\author{
河 野 洋 平*·薄良 彦*.引原 隆 士* \\ Applications of Koopman Mode Decomposition to Modeling of Heat Transfer Dynamics \\ in Building Atriums-II \\ -Advection by Large-scale Air Movement-
}

Yohei Kono*, Yoshihiko Susuki* and Takashi HikinarA*

\begin{abstract}
We develop a methodology for modeling of heat transfer dynamics of building atriums based on observational data on temperature and air-conditioning system. Following the companion paper [Y. Kono, Y. Susuki, M. Hayashida, and T. Hikihara, Trans. SICE 53-2], we focus on the phenomenon of heat transfer mainly due to the air movement inside a practically-used atrium, where the air slowly moves over the distance between individual rooms. The heat transfer is modeled as a two-dimensional advection equation with a coarse-grained velocity. The velocity is identified based on a spatio-temporal oscillatory pattern extracted from measurement data via Koopman mode decomposition. The identified velocity is verified with the characteristic numbers of fluid flow in the atrium and its architectural geometry.
\end{abstract}

Key Words: building, atrium, advection, coarse-graining, Koopman mode decomposition

\section{1.はじめに}

本論文は，ビルに対するエネルギーマネジメントシステム (Building Energy Management System: BEMS)に向け た，ビル内アトリウムの熱移動モデリングに関するものであ る. BEMS は, 空調, 照明などのエネルギー消費設備の監視, 制御㧍よびデー夕管理を複合的に行なうシステムであり，省 エネルギー性，低環境負荷性および快適性の維持ないし向上 を目的として導入される ${ }^{1), 2)}$. BEMS の重要な機能である 空調運用では，ビル内熱ダイナミクスの複数の時空間スケー ルに対する数理モデルが必要とされ，主に室内スケールの分 布定数モデル 3) 5) と部屋間の熱収支に着目した集中定数モデ ル6)に大別される。後者のモデルに関して，アトリウムを有 するビルでは, 空調給気などに起因する室内温度の変化が主 にアトリウムを介して空間的に伝搬することになる。この伝 搬にかかわる評価のための 1 つの方策として，アトリウムを 介した熱移動の数理モデルの構築が考えられる.

本論文は，アトリウムを介した部屋間熱移動ダイナミクスに 着目し，実測データを用いた数值流体力学（Computational

* 京都大学大学院工学研究科 京都市西京区京都大学桂

* Graduate School of Engineering, Kyoto University, Kyotodaigaku-katsura, Nishikyo-ku, Kyoto

(Received March 30, 2016)

(Revised September 10, 2016)
Fluid Dynamics: CFD) によらないモデル化を提案するもの であり，2 部から構成される。第 1 部 7 )では, アトリウム内に おいて部屋間空間スケールより小さい流速場構造が支配的と なる場合を対象に，部屋間の熱移動を拡散方程式としてモデ ル化した。これに続く第 2 部として，本論文では，アトリウ ム内に拈いて部屋間空間スケールより大きい流速場構造が支 配的となる場合を対象に, 部屋間の熱移動を移流方程式とし てモデル化する．そして，クープマンモード分解 (Koopman

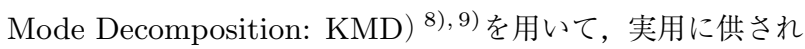
ているビルで得られた実測データより，アトリウムを介した 熱移動の時間スケールに相当する時空間振動成分を抽出し, その応答に基づきモデルパラメータを同定する，以上により， 第 1 部と合わせ，実測デー夕を利用することでビル内アトリ ウムに㧍ける熱移動の定量的な特性評価が可能となることを 示す.

本論文の構成は以下のとおりである. 2 章では, 第 2 部で 対象とするビルとそこで得られた実測データについて説明す る. 3 章では, 空調による熱入力を実測デー夕を用いてモデ ル化し，実測温度データおよび熱入力データに対して KMD を適用した結果を示す４４章では，アトリウムを介した熱移 動の物理メカニズムについて説明し，これを表現するために 粗視化した移流項を用いた数理モデルを提案する. 5 章では, 4 章で導入したモデルのパラメータを実測データの KMD 結 果を用いて同定し，その妥当性を流速場の特性数㧍よび建物 


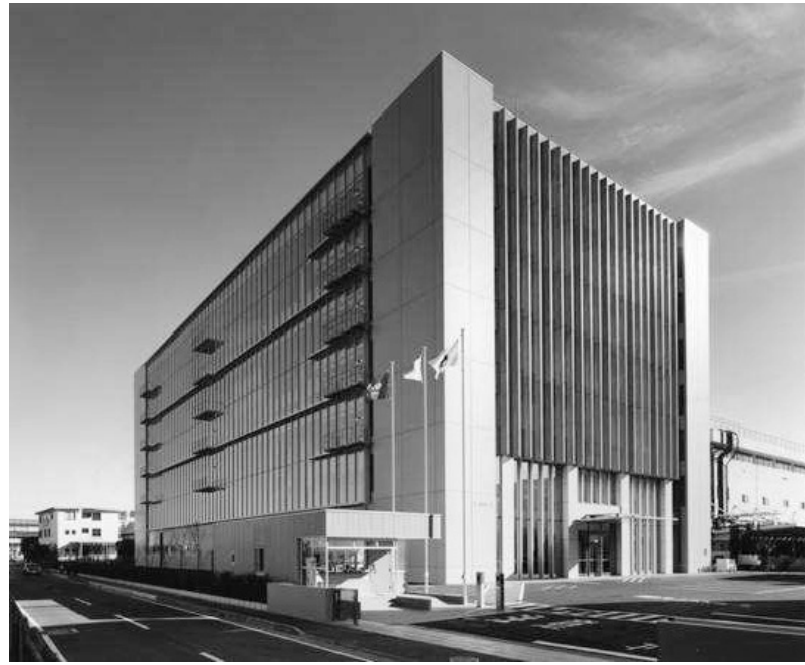

Fig. 1 Photograph of the target building

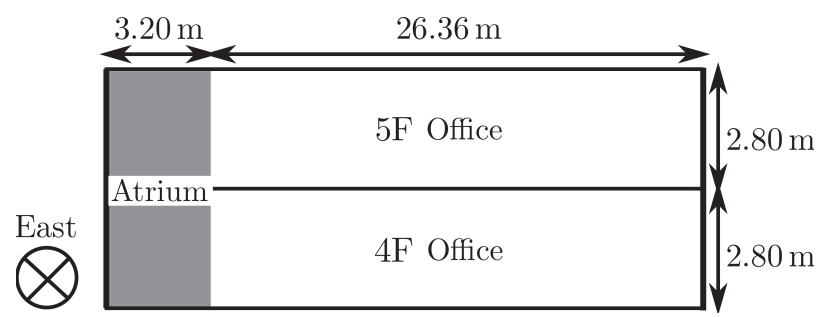

Fig. 2 Cross section of the target building

構造の点から検討する. 6 章では, 本論文をまとめると共に, 第 1 部と合わせて提案方法の妥当性と今後の展望について述 ベる.

\section{2. 解析対象のビルおよび実測データ}

本章では，解析対象とするビル内アトリウムについて説明 すると共に, 熱移動ダイナミクスのモデル化に用いる実測デー 夕を紹介する。

本論文で対象とするのは，アズビル（株）研究棟である. Fig. 1 に対象ビルの外観写真を, Fig. 2, Fig. 3 に対象ビル の断面図拈よび平面図を示す，図中の実線は壁を，破線は空 調の給気エリアに対応する部屋内の境界を表わす。さらに， 黒塗りの正方形は室内の柱を，白塗りの長方形は棚を表わす. 対象とする空間はビルの 4 階抒よび 5 階部分であり，その北 側はアトリウムを介して壁に仕切られることなく連続的につ ながっている. Fig. 4 に本アトリウムの構造を写真で示す.

つぎに，対象ビルの空調設備について説明する．対象の空 間では各階に外部熱源を有する大型の空調機 (Air Handling Unit: AHU) が4つ設置されている. また, 各 AHUはそれぞ れ 3 つの可変風量方式空調機 (Variable Air Volume System: VAV System)に接続されており, AHUで生成した熱は各 VAV により室内に分配される。本論文では，各 AHUをそれぞれ AHU1 から AHU4 と呼び, さらに $\mathrm{AHU} n_{\mathrm{A}}\left(n_{\mathrm{A}}=1, \ldots, 4\right)$ に接続された 3 つの VAV をそれぞれ $\mathrm{VAV} n_{\mathrm{A}}-1, \mathrm{VAV} n_{\mathrm{A}^{-}}-2$,

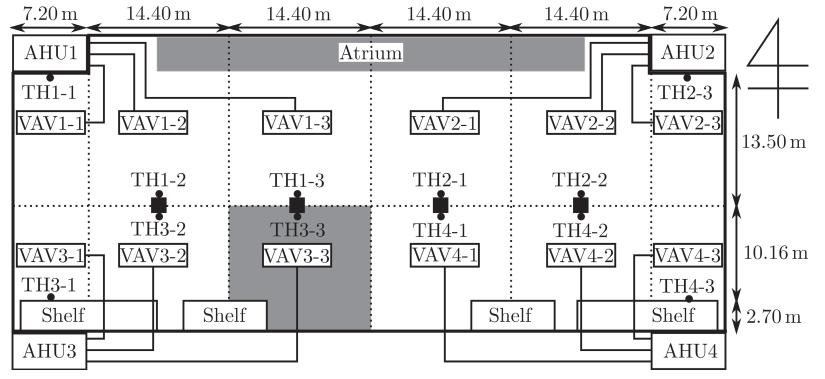

Fig. 3 Outline of 4 th and 5th floors of the target building. The circles stand for in-room temperature sensors and the rectangles for VAV units and AHU units

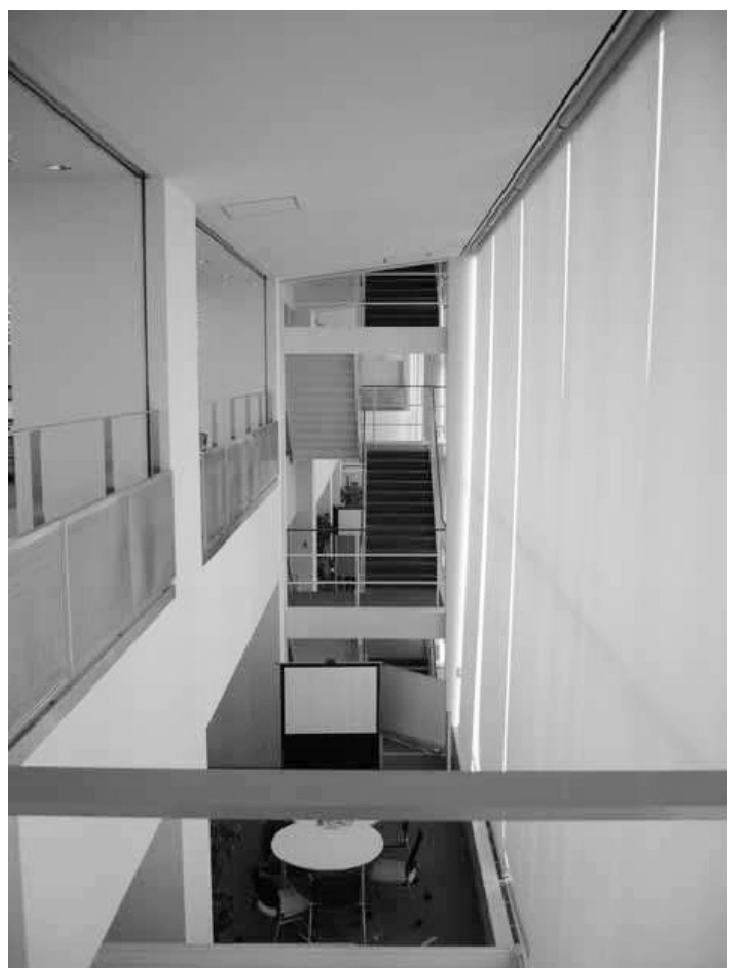

Fig. 4 Photograph of atrium in the target building

$\mathrm{VAV} n_{\mathrm{A}}-3$ と呼ぶ。なお, 各 $\mathrm{VAV}$ は複数のダクトを有してお り，それらを介して室内に給気する。さらに，Fig. 5 に示す ように局所向けの空調機（Perimeter Unit: PU）が 4 階に 6 機， 5 階に 4 機設置されている。縞模様の長方形が上記空調 機の給気ダクトを表わす，本論文ではこれらを図中に示すよ うに各階ごとにPU1 から PU6 と呼ぶこととする.PU1 お よび PU2 の給気ダクトは天井面に設置されており，アトリウ ム内で下向きの給気を行なっている。PU3 および PU4 も同 様に天井面に設置されたダクトから空に向けて給気を行なっ ている. 4 階の PU5 およびPU6 に関しては, 床面付近から 上向きに給気を行なっている。

続いて, 解析対象で実測されたデータについて説明する. 対象の空間では, 室内温度, 空調機の給気温度および給気風量 が，それぞれ 1 分ごとに $0.1^{\circ} \mathrm{C}$ 刻みあるいは $1 \mathrm{~m}^{3} / \mathrm{h}$ 刻みで 実測されている，室内温度は各階 12 箇所に設置された温度計 


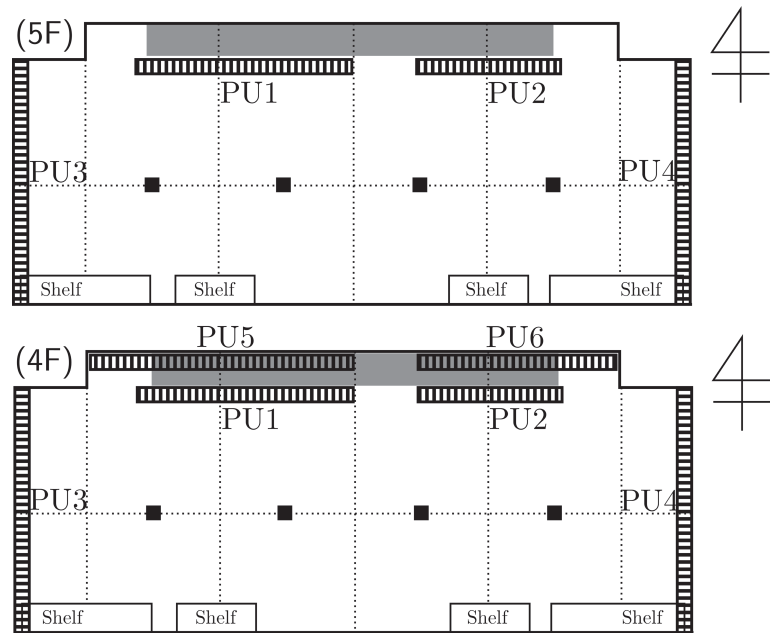

Fig. 5 Outlet ducts of HVAC units in perimeter zone of the target building. PU1 to PU4 are located on the ceiling and generate downward air flow. On the other hand, PU5 and PU6 are located near the floor and generate upward air flow

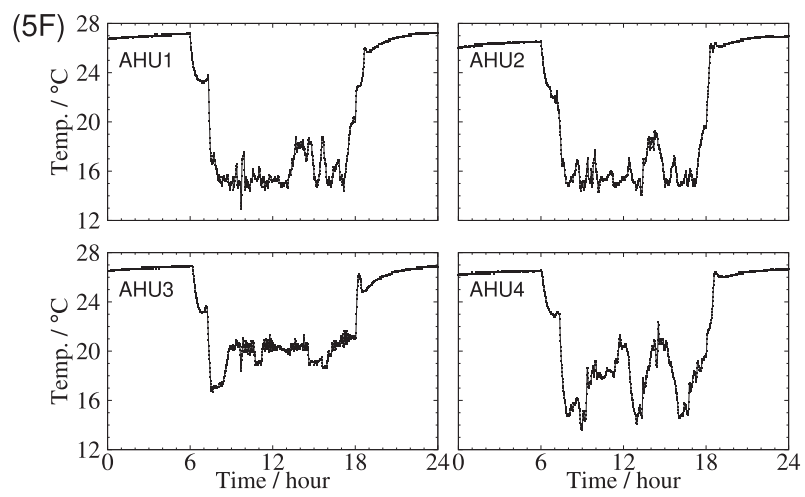

(4F)

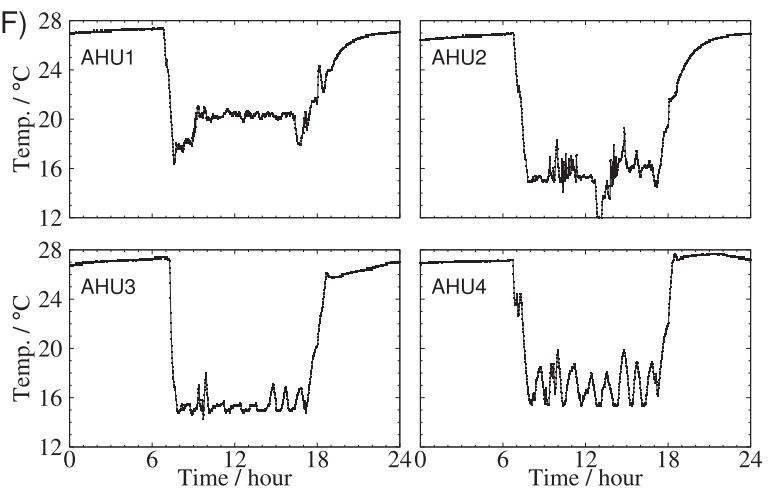

Fig. 8 Outlet temperature of AHUs sampled on August 1, 2014 (Fri.)

で実測されている．以後，これらの温度計を Fig. 3 に示すよ うにTH1-1 から TH4-3 と呼ぶ. TH1-1, TH2-3, TH3-1, およびTH4-3 はそれぞれ壁および棚に設置されており，それ 以外の温度計は柱に設置されている。給気風量は, VAVの給 気風量として各階 12 箇所で実測されている。一方, 給気温 度は各階 4 つの AHU 内部で実測されている．また，局所向 け空調に関しては，4階の PU1, PU2 および 5 階の PU1 か ら PU4の給気温度および風量のみが実測されている。
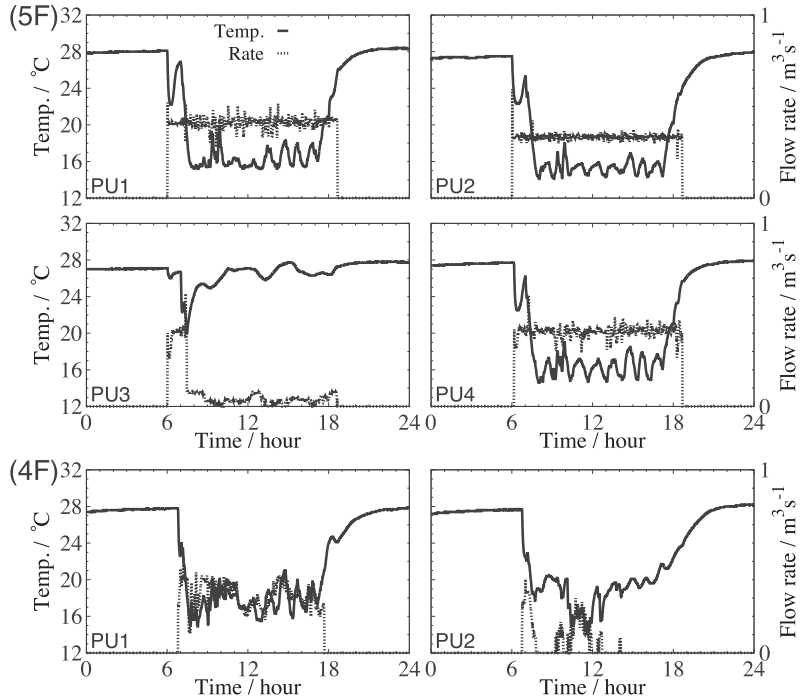

Fig. 9 Outlet temperature and volume of PUs sampled on August 1, 2014 (Fri.)

最後に，解析対象とする実測デー夕を紹介する．ここでは 2014 年 8 月 1 日（金）に実測されたデータを示す.Fig. 6 に 4 階および 5 階の室内温度を, Fig. 7 にVAVの給気風 量を, Fig. 8 に AHU の給気温度デー夕を示す. 室内温度の 変動に応じて給気温度および風量が変化しており, VAV 型 の空調機が動作していることが確かめられる，たとえば，午 前 8 時および午後 1 時付近において，5階では TH2-1 から TH2-3 および TH4-1 から TH4-3 で室内温度が急変している (Fig. 6 を参照)。これに応じて，当該時刻における AHU2 お よび AHU4 の給気風量が変化している (Fig. 7 を参照)。ま た, Fig. 8 を見ると, AHU4 の給気温度が上記の温度変動に 応じて増減していることが確かめられる。ささらに, Fig.9に PUの給気温度および風量を示す．各位置において給気温度 および風量が異なっており，局所的な負荷に応じて空調が動 作していることが確かめられる。

\section{3. 温度データのクープマンモード分解}

本章では, Fig. 6〜Fig. 9 に示した実測データに KMD を 適用し, データに内在する時空間振動モードを抽出する. KMD の詳細については第 1 部を参照されたい. 第 1 部と 同様に, Arnoldi 型アルゴリズム ${ }^{9)}$ を用いて実測データ列 $\boldsymbol{X}[n] \in \mathbb{R}^{M}(n=0, \ldots, N-1)$ を以下のように有限級数 へと分解する。

$$
\left\{\begin{array}{l}
\boldsymbol{X}[n]=\sum_{m=1}^{N-1} \tilde{\lambda}_{m}^{n} \tilde{\boldsymbol{V}}_{m}, \quad n \in\{0, \ldots, N-2\} \\
\boldsymbol{X}[N-1]=\sum_{m=1}^{N-1} \tilde{\lambda}_{m}^{N-1} \tilde{\boldsymbol{V}}_{m}+\boldsymbol{R}
\end{array}\right.
$$

ここで, $\tilde{\lambda}_{m}$ および $\tilde{\boldsymbol{V}}_{m}$ はクープマン固有值 (Koopman Eigenvalue: KE) およびクープマンモード (Koopman Mode: KM) と呼ばれる。また， $R$ は分解にあたり生じる剩余べクトルで 

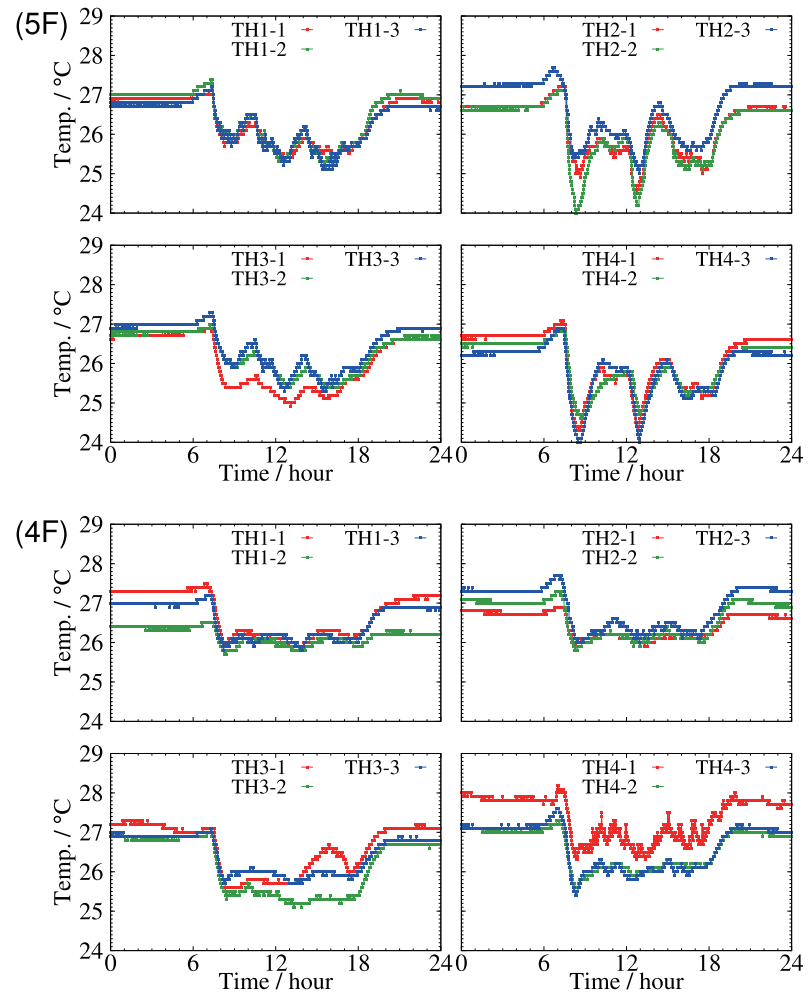

Fig. 6 In-room temperature sampled on August 1, 2014 (Fri.)
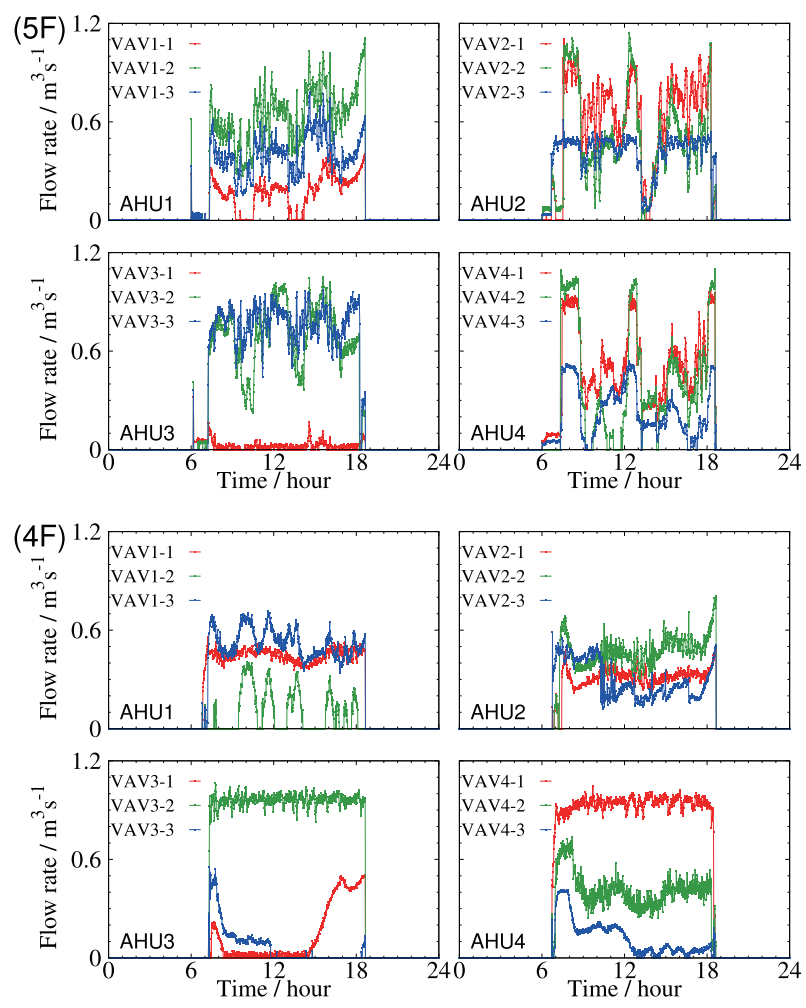

Fig. 7 Outlet volume of VAVs sampled on August 1, 2014 (Fri.)

あり, 一般にそのノルムは小さい.

ここで，KMD の対象とするデータについて述べる．本論 文では, 午前 8 時から午後 17 時までの 9 時間を対象とし, 室

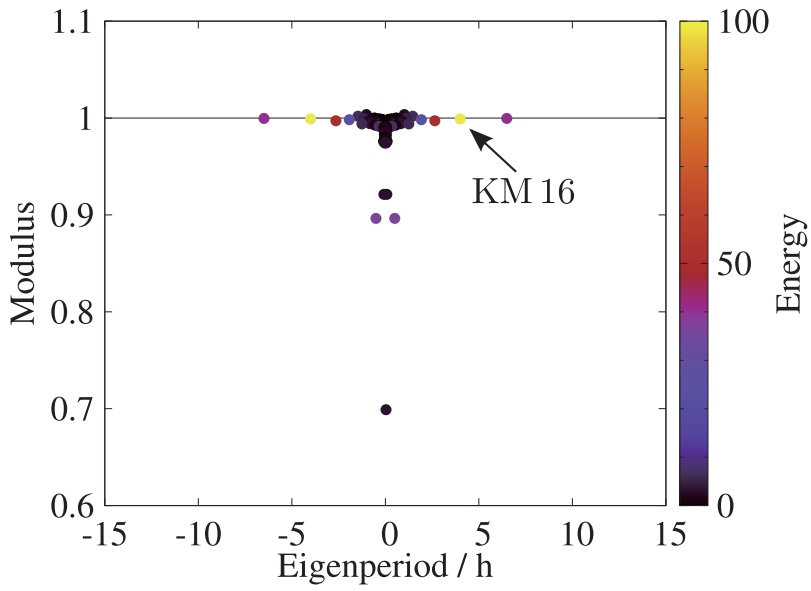

Fig. 10 Plot of Koopman spectrum with contained modal energy

内温度データ $\boldsymbol{T}[n] \in \mathbb{R}^{24}$ (Fig. 6) と実測データから構成さ れる熱入力 $\boldsymbol{P}[n] \in \mathbb{R}^{24}(n=0, \ldots, 540)$ に対して KMD を 適用する。この場合, $\boldsymbol{X}[n]=\left[\boldsymbol{T}[n]^{\top} \boldsymbol{P}[n]^{\top}\right]^{\top}$ (添字 Тは心 クトルの転置）かつ $M=48, N=541$ （9 時間に相当）で ある. 対象ビルに設置されている空調機は第 1 部の場合と異 なりVAV 型であるため，下記のように給気風量の変化を考 慮して解析を行なう. 熱入力 $\boldsymbol{P}[n]$ の各成分 $P_{n}\left[i_{\mathrm{h}}\right]$ は Bulk convection ${ }^{6)}$ の形式から次式で与えられる.

$$
\begin{aligned}
& P_{n}\left[i_{\mathrm{h}}\right]= \frac{V_{n}^{(1)}\left[i_{\mathrm{h}}\right]\left(T_{n}^{\mathrm{H}, 1}\left[i_{1}\right]-T_{n}\left[i_{\mathrm{h}}\right]\right)}{V_{0}\left[i_{\mathrm{h}}\right]} \\
&+\frac{V_{n}^{(2)}\left[i_{\mathrm{h}}\right]\left(T_{n}^{\mathrm{H}, 2}\left[i_{\mathrm{h}}\right]-T_{n}\left[i_{\mathrm{h}}\right]\right)}{V_{0}\left[i_{\mathrm{h}}\right]}, \\
& i_{\mathrm{h}}:=3 i_{1}+i_{2}-3, \quad i_{1}=1, \ldots, 4, i_{2}=1,2,3
\end{aligned}
$$

ここで, $T_{n}\left[i_{\mathrm{h}}\right]$ は $\mathrm{TH} i_{1}-i_{2}$ の温度デー夕（すなわち $\boldsymbol{T}[n]$ の 成分), $V_{n}^{(1)}\left[i_{\mathrm{h}}\right]$ は VAV $i_{1}-i_{2}$ の給気風量デー夕 (Fig. 7) を, $T_{n}^{\mathrm{H}, 1}\left[i_{1}\right]$ は $\mathrm{AHU} i_{1}$ の給気温度デー夕（Fig. 8）を表わす。ま た， $V_{n}^{(2)}\left[i_{\mathrm{h}}\right]$ および $T_{n}^{\mathrm{H}, 2}\left[i_{\mathrm{h}}\right]$ は PU1 から PU4 の給気風量お よび温度デー夕（Fig.9）を表わしており，TH $i_{1}-i_{2}$ の位置に PU1 から PU4 のダクトがある場合のみ非零の值を取り，そ れ以外の位置では零となる。さらに, $V_{0}\left[i_{\mathrm{h}}\right]$ は $\mathrm{VAV} i_{1}-i_{2}$ の 給気ダクト位置に対応するエリアの体積（Fig. 3 の破線で囲 まれた部分，たとえば影付きの領域を参照）を表わす.

以上のデータセット $\boldsymbol{X}[n]$ に KMD を適用した結果を示す. 第 1 部と同様に，本論文では $\mathrm{KM} \tilde{\boldsymbol{V}}_{m}$ を以下の 2 成分に分 解し検討する。

$$
\tilde{\boldsymbol{V}}_{m}=\left[\begin{array}{c}
\boldsymbol{V}_{m}^{\mathrm{I}} \\
\boldsymbol{V}_{m}^{\mathrm{H}}
\end{array}\right]
$$

ただし， $\boldsymbol{V}_{m}^{\mathrm{I}}, \boldsymbol{V}_{m}^{\mathrm{H}} \in \mathbb{C}^{24}$ は $\mathrm{KM}$ の成分のうち，それぞれ室 内温度 $\boldsymbol{T}[n] \in \mathbb{R}^{24}$ と熱入力 $\boldsymbol{P}[n] \in \mathbb{R}^{24}$ に対応する部分の モードベクトルである， $\boldsymbol{X}[n]$ が実数值ベクトルであるため, KE および KM には互いに複素共役なものが含まれる，以下 では複素共役なモードベクトルの対をモード対 $\{m, m+1\}$ 
$(a-1)$

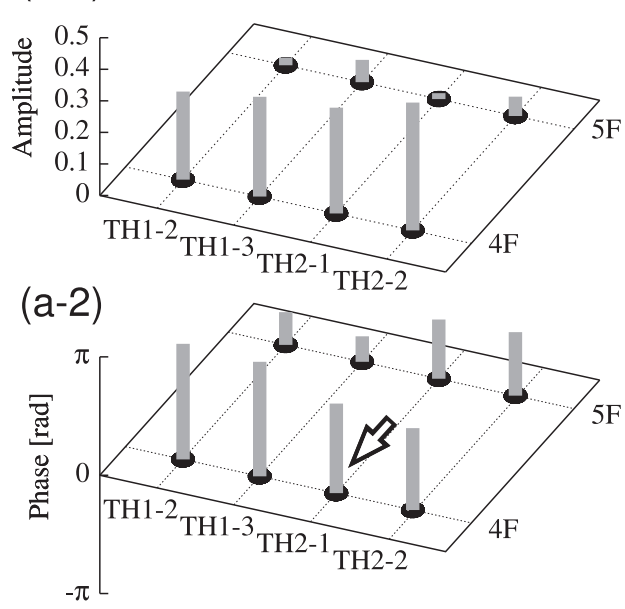

(b-1)

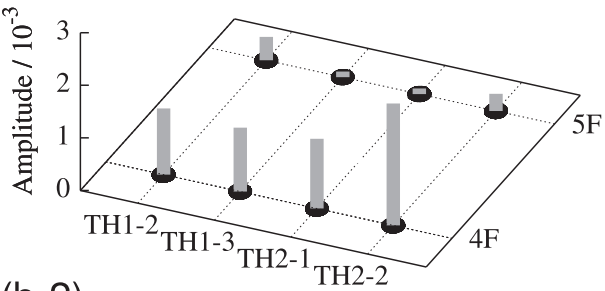

(b-2)

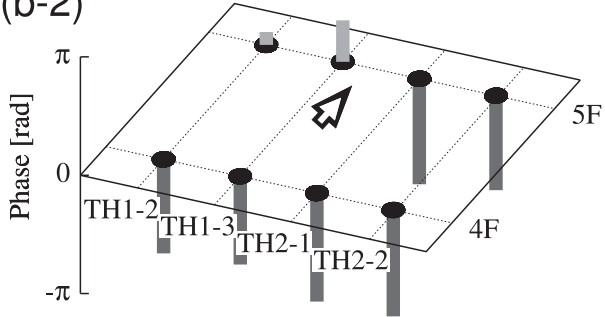

Fig. 11 Amplitude and phase of Koopman mode $\tilde{\boldsymbol{V}}_{16}$ shown in Table 1: (a-1,a-2) $\boldsymbol{V}_{16}^{\mathrm{I}}$ of atrium temperature, where the arrow represents the direction of the calculated wavenumber vector $\boldsymbol{k}_{16}^{\mathrm{I}}$, and (b-1,b-2) $\boldsymbol{V}_{16}^{\mathrm{H}}$ of outlet temperature, where the arrow represents the direction of the calculated wavenumber vector $\boldsymbol{k}_{16}^{\mathrm{H}}$

Table 1 Koopman mode decomposition of the data measured on August 1, 2014 (Fri.)

\begin{tabular}{ccccc}
\hline$\{m, m+1\}$ & $\left|\lambda_{m}\right|$ & $T_{m} / \mathrm{h}$ & $\left\|\boldsymbol{V}_{m}^{\mathrm{I}}\right\|$ & $\left\|\boldsymbol{V}_{m}^{\mathrm{H}}\right\|$ \\
\hline$\{1,2\}$ & 1.0036 & 1.014 & $2.68 \times 10^{-2}$ & $3.76 \times 10^{-4}$ \\
$\{3,4\}$ & 1.0019 & 1.466 & $8.59 \times 10^{-2}$ & $9.46 \times 10^{-4}$ \\
$\{5,6\}$ & 1.0001 & 0.583 & $3.00 \times 10^{-2}$ & $6.92 \times 10^{-4}$ \\
7 & 1.0000 & $\infty$ & $1.27 \times 10^{2}$ & $4.63 \times 10^{-2}$ \\
$\{8,9\}$ & 0.9997 & 1.151 & $1.46 \times 10^{-1}$ & $1.86 \times 10^{-3}$ \\
$\{10,11\}$ & 0.9997 & 6.490 & $4.24 \times 10^{-1}$ & $6.01 \times 10^{-3}$ \\
$\{12,13\}$ & 0.9995 & 0.634 & $4.16 \times 10^{-2}$ & $7.30 \times 10^{-4}$ \\
$\{14,15\}$ & 0.9992 & 0.381 & $4.83 \times 10^{-2}$ & $8.39 \times 10^{-4}$ \\
$\{\mathbf{1 6}, \mathbf{1 7}\}$ & 0.9991 & $\mathbf{3 . 9 9 9}$ & $\mathbf{1 . 0 6}$ & $\mathbf{7 . 6 6} \times \mathbf{1 0}^{-\mathbf{3}}$ \\
$\{18,19\}$ & 0.9989 & 0.272 & $3.45 \times 10^{-2}$ & $7.38 \times 10^{-4}$ \\
\hline
\end{tabular}

と呼ぶ. Table 1 に各モード対に関する諸量を, $\left|\tilde{\lambda}_{m}\right|$ が大 きい順に示す。ただし $\|\cdot\|$ はべクトルノルムである。また， 固有周期 $T_{m}$ は以下で求められる.

$$
T_{m}=\frac{2 \pi \Delta t}{\left|\operatorname{Im}\left[\ln \tilde{\lambda}_{m}\right]\right|}
$$

ここで, $\Delta t$ はサンプリング周期で 1 分である. KEが 1 の $\mathrm{KM}$ 7 は元データ中のバイアス成分に対応する。 それ以外の KM のうち, KEが 1 に近くかつノルムの大きいモード対 $\{16,17\}$ を元データ中の支配的なモードとして見なす．元データ中に は, 固有周期 $T_{16}=3.999 \mathrm{~h}$ に近い振動成分が確認され，本 モード対はこの成分に対応すると考えられる（詳細は付録 A の周波数スペクトルを参照).なお, モード対 $\{10,11\}$ も ルムが大きいが, 固有周期 $T_{10}=6.490 \mathrm{~h}$ に対応する成分は 元データ中に見受けられないため, 本論文では検討対象とは しない（詳細は付録 $\mathrm{A}$ の周波数スペクトルを参照).

つぎに，すべての KM に関する諸量を示す．Fig. 10 に各 $\mathrm{KM}$ の固有周期 $T_{m}$, 絶対值 $\left|\tilde{\lambda}_{m}\right|$, エネルギー $E_{m}$ を示す. ここで, $\mathrm{KM}$ のエネルギー $E_{m}$ は振動応答の 2 乗積分に基づ き次式で与える.

$$
E_{m}=\sum_{n=0}^{N-1}\left\|\operatorname{Re}\left[\tilde{\lambda}_{m}^{n} \tilde{\boldsymbol{V}}_{m}\right]\right\|^{2}
$$

なお, 各 $\mathrm{KM}$ の振動応答の部分和 $\boldsymbol{S}_{N_{\mathrm{p}}}[n]:=\sum_{m=1}^{N_{\mathrm{p}}} \operatorname{Re}\left[\tilde{\lambda}_{m}^{n} \tilde{\boldsymbol{V}}_{m}\right]$ $\left(N_{\mathrm{p}} \in\{1, \ldots, N-1\}\right)$ を求めたところ，元データとの間の 2 乗積分誤差 $\sum_{n=0}^{N-1}\left\|\boldsymbol{X}[n]-\boldsymbol{S}_{N_{\mathrm{p}}}[n]\right\|^{2}$ が $N_{\mathrm{p}}$ の増加に伴い 0 に 近づくことを確認した. よって，（5）式のエネルギーは，各 KM の元データに対する寄与の評価指標として妥当であると 考えられる.モード対 $\{16,17\}$ を見ると， $\left|\tilde{\lambda}_{m}\right|$ がほぼ 1 で ありかつエネルギーが最も大きく，支配的なモードであるこ とが確かめられる。

続いて, 上記の支配的な KM の振幅および位相の空間分布 を示す. Fig. 11(a-1,a-2) に抽出した KM $\boldsymbol{V}_{16}^{\mathrm{I}}$ の振幅および 位相を, Fig. 11(b-1,b-2)にKM $\boldsymbol{V}_{16}^{\mathrm{H}}$ の振幅および位相をそれ ぞれ示す。ただし，アトリウムに接する位置 TH1-2, TH1-3, $\mathrm{TH} 2-1$ ，およびTH2-2での成分のみを示している．眓中の矢 印は， $\boldsymbol{V}_{16}^{\mathrm{I}}$ および $\boldsymbol{V}_{16}^{\mathrm{H}}$ に対応する波数べクトル $\boldsymbol{k}_{16}^{\mathrm{I}}$ および $\boldsymbol{k}_{16}^{\mathrm{H}}$ を東西方向 $\times$ 高さ方向の 2 次元平面に射影したものに対 応する (算出方法は第 1 部を参照). Fig. 11(a-1,b-1) 共に 4 階で振幅が大きくなっていることから, 各位置の温度が空調 給気に応じて変動していると考えられる. また, Fig. 11(a-2) からわかるように KM $\boldsymbol{V}_{16}^{\mathrm{I}}$ の位相には空間的な差異が存在す る。これはアトリウムを介して波数べクトル $\boldsymbol{k}_{16}^{\mathrm{I}}$ の方向の熱 移動が生じていることを表わしている.さらに, Fig. 11(b-2) の位相分布は Fig. 11(a-2) と対応しておらず，かつ波数べク トル $\boldsymbol{k}_{16}^{\mathrm{H}}$ が $\boldsymbol{k}_{16}^{\mathrm{I}}$ の反対方向であることから，ビル内に分散配 置された空調機群が上記熱移動を打ち消そうと動作している ことが推察される。なお，この空調機群の動作は各空調機の ローカルな制御により出現したものであり, アトリウム全体 
の熱移動を陽に考慮したグローバルな空調制御として意図し たものではない.よって，熱移動を完全に打ち消すことはで きておらず，結果としてモード対 $\{16,17\}$ が顕在化したもの と考えられる。

\section{4. 熱移動の物理メカニズムと数理モデル 一低波数成分による移流}

本章では，階ごとの空間スケールで粗視化したアトリウム 内の熱移動ダイナミクスのモデル化を行なう。第 1 部で述べ たように，階間高さに対応する粗視化スケール $L_{\mathrm{c}}$ を用いて， 流速 $\boldsymbol{u}(\boldsymbol{r})$ は次式のように高波数成分と低波数成分に分解さ れる。

$$
\boldsymbol{u}(\boldsymbol{r})=\boldsymbol{u}_{\mathrm{H}}(\boldsymbol{r})+\boldsymbol{u}_{\mathrm{L}}(\boldsymbol{r})
$$

ここで

$$
\begin{aligned}
& \boldsymbol{u}_{\mathrm{H}}(\boldsymbol{r})=\sum_{\|\boldsymbol{k}\| \geq k_{\mathrm{C}}} \tilde{\boldsymbol{u}}(\boldsymbol{k}) \exp (\mathrm{i} \boldsymbol{k} \cdot \boldsymbol{r}) \\
& \boldsymbol{u}_{\mathrm{L}}(\boldsymbol{r})=\sum_{0<\|\boldsymbol{k}\|<k_{\mathrm{C}}} \tilde{\boldsymbol{u}}(\boldsymbol{k}) \exp (\mathrm{i} \boldsymbol{k} \cdot \boldsymbol{r})
\end{aligned}
$$

であり, $\tilde{\boldsymbol{u}}(\boldsymbol{k})$ は流速場の波数成分, $\boldsymbol{k} \in \mathbb{R}^{3}$ は波数べクトル を表わす．なお， $k_{\mathrm{c}}=2 \pi / L_{\mathrm{c}}$ は粗視化スケールに対応する 波数であり，階間高さ $L_{\mathrm{c}}$ よりも波長の大きな成分と波長の 小さな成分を区別するために導入される、第 1 部では，アト リウム内で $\boldsymbol{u}_{\mathrm{H}}$ が支配的となる場合を対象に，熱移動の有効 熱拡散としての表現を試みた。本論文の第 2 部では， $\boldsymbol{u}_{\mathrm{L}}$ が 支配的となる場合を対象に，熱移動を移流方程式としてモデ ル化する。

まず，流速場の構造を考慮し，ビル内の領域を分割する。 本論文では，Fig. 12 に示すように，ビル内の空間 $S \subset \mathbb{R}^{3}$ をアトリウムを表わす領域 $S_{\mathrm{atr}} \subset \mathbb{R}^{3}$ と室内を表わす領域 $S_{\text {ofc } 4}, S_{\text {ofc5 }} \subset \mathbb{R}^{3}$ に分割する。そして，アトリウムと室内に 対して異なる数理モデルを導出する，すなわち，本論文では， 第 1 部 ${ }^{7)}$ の場合と異なり室内 $S_{\mathrm{ofc} 4}$ および $S_{\mathrm{ofc} 5}$ での熱移動 ダイナミクスを考慮したアトリウム内熱移動ダイナミクスの 解析を行なう。これは，5 章でモデルパラメータの同定を行 なうにあたり，室内からの熱入力によるアトリウム内温度分 布への効果を正確に反映させるためである，ビル内に設置さ れている空調機はすべて VAV 型であり (2 章を参照), アト リウムに流入する熱量は時空間的に大きく変動する。これら

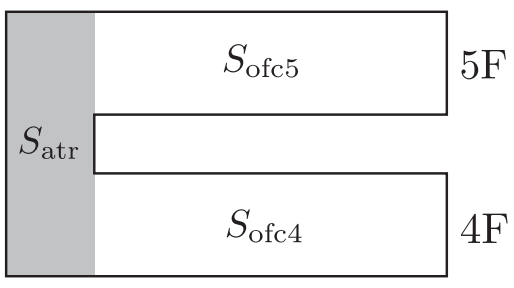

Fig. 12 Target region $S \in \mathbb{R}^{3}$ and its subsets $S_{\text {atr }}, S_{\text {ofc } 4}$, and $S_{\text {ofc5 }}$
の影響を陽に考慮するべく，本論文ではアトリウム内 $S_{\mathrm{atr}}$ た けでなく室内 $S_{\mathrm{ofc} 4}$ および $S_{\mathrm{ofc} 5}$ の熱ダイナミクスを同時に 扱い，アトリウムにおける熱移動のパラメータ同定を行なう.

つぎに，アトリウム内熱移動の具体的なモデル化について 説明する．内部に空調給気ダクトを有する機械換気型アトリ ウムでは，流速場において階間高さよりスケールの大きな成 分 $\boldsymbol{u}_{\mathrm{L}}$ が支配的だと考えられる。よっ，アトリウム内の位 置 $\boldsymbol{x}:=(x, z)^{\top}$ および時刻 $t$ における 2 次元温度分布 $T$ は つぎの移流方程式に従う.

$$
\begin{aligned}
\left\{\frac{\partial}{\partial t}+\boldsymbol{u}_{\mathrm{L}}(\boldsymbol{x}) \cdot \nabla\right\} T(\boldsymbol{x}, t) & =\frac{P_{\mathrm{HVAC}}(\boldsymbol{x}, t)+e(\boldsymbol{x}, t)}{\rho c_{\mathrm{p}}}, \\
\boldsymbol{x} & \in A \subset \mathbb{R}^{2}
\end{aligned}
$$

ここで， $\boldsymbol{\nabla}$ は座標 $\boldsymbol{x}$ に関するべクトル微分作用素， $P_{\mathrm{HVAC}}$ は空調機による単位時間および単位体積あたりの熱入力, $e$ は そのほか熱源および室内熱ダイナミクスに起因する熱入力， $\rho$ および $c_{\mathrm{p}}$ は空気の密度および定圧比熱，Aはアトリウム内 を表わす 2 次元領域（幅方向 $\times$ 高さ方向）である.ただし， 分子熱拡散係数は一般に小さいことから拡散項の寄与を無視 した．今，階間スケールで粗視化した熱ダイナミクスを扱う ため，面積 $\left|A_{\mathrm{c}}\right|$ を有する有界領域 $A_{\mathrm{c}} \subset A$ で粗視化したパ ラメータ $U_{x}$ および $U_{z}$ をつぎのように導入する.

$$
\begin{aligned}
U_{x} & =\frac{1}{\left|\partial A_{\mathrm{c} x}\right|} \int_{\partial A_{\mathrm{c} x}} \boldsymbol{u}_{\mathrm{L}}(\boldsymbol{x}) \cdot \boldsymbol{n}_{1} \mathrm{~d} s, \quad x=x_{1}, x_{2} \\
U_{z} & =\frac{1}{\left|\partial A_{\mathrm{c} z}\right|} \int_{\partial A_{\mathrm{c} z}} \boldsymbol{u}_{\mathrm{L}}(\boldsymbol{x}) \cdot \boldsymbol{n}_{2} \mathrm{~d} s, \quad z=z_{1}, z_{2}
\end{aligned}
$$

ここで, $\partial A_{\mathrm{c} x}$ および $\partial A_{\mathrm{c} z}$ は領域 $A_{\mathrm{c}}$ の境界要素, $\left|\partial A_{\mathrm{c} x}\right|$ お よび $\left|\partial A_{\mathrm{c} z}\right|$ はその長さ， $\boldsymbol{n}_{1}$ および $\boldsymbol{n}_{2}$ は $x$ 軸正方向および $z$ 軸正方向の単位ベクトルである (Fig. 13 を参照). (10) お よび（11）式では領域 $A_{\mathrm{c}}$ に対して垂直な流入出量を評価し ている， $\boldsymbol{u}_{\mathrm{L}}$ は領域 $A_{\mathrm{c}}$ よりも大きな空間スケールを有してい ることから，非垂直成分，すなわち非対角成分を用いること なく垂直成分のみを用いて移流項の寄与を評価できる．本論 文では， $U_{x}$ および $U_{z}$ を有効流速と呼ぶ.

最後に, 事務室内 $S_{\mathrm{ofc} 4}$ および $S_{\mathrm{ofc} 5}$ での熱移動ダイナミク スのモデル化を行ない, 5 章の同定に用いる数理モデルを導出 する。まず，室内熱移動のモデル化について説明する．室内 の流速場においては, 粗視化領域 (Fig. 3 中の破線で囲まれた 各給気エリア）よりも小さなスケールの成分が支配的である と考えられる。これは，対象の室内では給気ダクトが各給気 エリアごとに 6 個程度設置されていることによる、給気ダク 卜は天井面から下向きに給気を行なっており，これにより給 気ダクト間隔程度のスケールを有する渦が誘起される ${ }^{5), 10)}$. このとき, 室内熱移動は粗視化により拡散として表現される (詳細は第 1 部 7) および文献 11),12) を参照)．以上を踏まえ ると，位置 $\boldsymbol{r} \in S$ および時刻 $t$ におけるビル内温度分布 $T$ は つぎのように表わされる.

$$
\left\{\frac{\partial}{\partial t}+\boldsymbol{u}\left(\boldsymbol{x}_{1}\right) \cdot \nabla_{1}\right\} T\left(\boldsymbol{x}_{1}, t\right)=\frac{P_{\mathrm{HVAC}}\left(\boldsymbol{x}_{1}, t\right)+e\left(\boldsymbol{x}_{1}, t\right)}{\rho c_{\mathrm{p}}},
$$




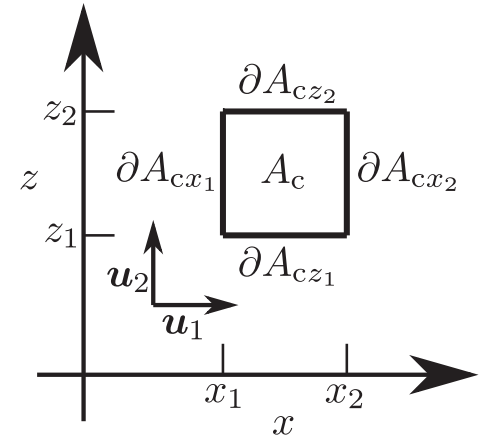

Fig. 13 The domain $A_{\mathrm{c}}$ used for coarse-graining and its boundaries $\partial A_{\mathrm{c} x}$ and $\partial A_{\mathrm{c} z}$, where $\boldsymbol{u}_{1}$ and $\boldsymbol{u}_{2}$ are the unit vectors in the directions of $x$ and $z$, respectively

$$
\boldsymbol{x}_{1}=\left[x_{1}, z_{1}\right]^{\top}, \boldsymbol{r}=\left[x_{1}, y_{1}, z_{1}\right]^{\top} \in S_{\text {atr }}
$$

$\frac{\partial}{\partial t} T\left(\boldsymbol{x}_{2}, t\right)=D_{\mathrm{e}}\left(\boldsymbol{x}_{2}\right) \Delta_{2} T\left(\boldsymbol{x}_{2}, t\right)$

$$
\begin{array}{r}
+\frac{P_{\mathrm{HVAC}}\left(\boldsymbol{x}_{2}, t\right)+e\left(\boldsymbol{x}_{2}, t\right)}{\rho c_{\mathrm{p}}}, \\
\boldsymbol{x}_{2}=\left[x_{2}, y_{2}\right]^{\top}, \boldsymbol{r}=\left[x_{2}, y_{2}, z_{2}\right]^{\top} \in S_{\mathrm{ofc} 4}
\end{array}
$$

$\frac{\partial}{\partial t} T\left(\boldsymbol{x}_{3}, t\right)=D_{\mathrm{e}}\left(\boldsymbol{x}_{3}\right) \Delta_{3} T\left(\boldsymbol{x}_{3}, t\right)$

$$
\begin{array}{r}
+\frac{P_{\mathrm{HVAC}}\left(\boldsymbol{x}_{3}, t\right)+e\left(\boldsymbol{x}_{3}, t\right)}{\rho c_{\mathrm{p}}}, \\
\boldsymbol{x}_{3}=\left[x_{3}, y_{3}\right]^{\top}, \boldsymbol{r}=\left[x_{3}, y_{3}, z_{3}\right]^{\top} \in S_{\mathrm{ofc} 5}
\end{array}
$$

ここで, $\nabla_{1}:=\left[\partial / \partial x_{1}, \partial / \partial z_{1}\right]^{\top}, \Delta_{2}:=\partial^{2} / \partial x_{2}^{2}+\partial^{2} / \partial y_{2}^{2}$, $\Delta_{3}:=\partial^{2} / \partial x_{3}^{2}+\partial^{2} / \partial y_{3}^{2}$ である。また， $D_{\mathrm{e}}$ は有効拡散係 数7),11),12) と呼ばれ，小スケール流速場による熱移動を表現 するパラメータである。（12）式では，アトリウムの奥行が幅 および高さと比べ小さいことから，奥行 $y$ を無視した 2 次元 熱移動に着目している。また，(13）式拈よび（14）式では, 室内の高さが幅および奥行と比べ小さいことから, 高さ $z$ を 無視した 2 次元熱移動に着目したモデル化を行なっている.

\section{5. モデルパラメータの同定}

本章では, Fig. 2 のアトリウムを対象に前章の数理モデル の実装を行ない，実測データに基づくモデルパラメータの同 定を行なう.

\section{1 数理モデルの実装}

本節では，数理モデルの実装を行なう。まず，空間方向の 離散化方法について説明する。つぎに，上記離散化のもとで 数理モデルを実装し，その妥当性について定量的に検討する. 対象とするアトリウムは内部に空調給気ダクトを有しており (2 章を参照)，それにより階間に渡る層流成分が発生する。 よって, 粗視化スケール $L_{\mathrm{c}}$ を階間高さから $4.2 \mathrm{~m}$ とおくと, アトリウム内の流速場では低波数成分 $\boldsymbol{u}_{\mathrm{L}}$ が支配的であると 推測される，以下では，実測データの KMD を基に離散化し た方程式を検討する。

まず，空間方向の離散化方法について述べる．本論文では， インデックス $i \in\{1, \ldots, 6\}$ (東西方向), $j \in\{1,2\}$ (南北 方向), $k \in\{1,2\}$ (高さ方向), $n=0, \ldots, N-1$ (時刻) を

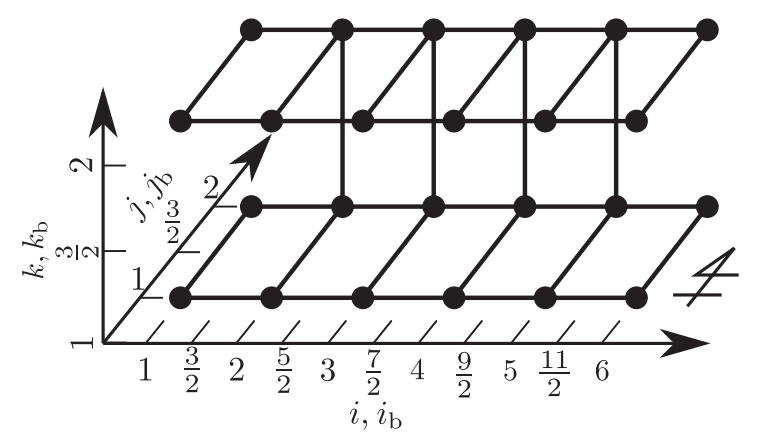

Fig. 14 Nodes and branches for space-discretization. The integer indices $i, j$, and $k$ stand for the length $x$, width $y$, and height $z$, respectively. The fractional indices $i_{\mathrm{b}}, j_{\mathrm{b}}$, and $k_{\mathrm{b}}$ stand for the branch between nodes $[i, j, k]$

用いて位置および時系列を表現した。また，第 1 部と同様に スタガード型の長方形格子 13)を用いた. Fig. 14 に離散化し たノードおよび枝を示す，図中の丸印は各ノードを，実線は ノード間の枝を表わす。そして，これらの枝の上にパラメー 夕を定義する． $k$ 方向の枝が $[i, j]=[2,2],[3,2],[4,2],[5,2]$ の 4 点のみに定義されているのは, $z$ 方向の熱ダイナミクス としてこれらの枝に対応するアトリウムを介した熱移動のみ に着目するためである。

つぎに，(12）式，(13）式および（14）式の離散化形式を 下記のとおり実装する (複号同順).

$$
\begin{array}{r}
\frac{T[i, j, k, n+1]-T[i, j, k, n]}{\Delta t}= \\
\sum_{i_{\mathrm{b}}=i \pm \frac{1}{2}} D_{i_{\mathrm{b}}, j, k} \frac{T[i \pm 1, j, k, n]-T[i, j, k, n]}{\left(\Delta x_{i_{\mathrm{b}}, j, k}\right)^{2}} \\
+\sum_{j_{\mathrm{b}}=j \pm \frac{1}{2}} D_{i, j_{\mathrm{b}}, k} \frac{T[i, j \pm 1, k, n]-T[i, j, k, n]}{\left(\Delta x_{i, j_{\mathrm{b}}, k}\right)^{2}} \\
+\sum_{k_{\mathrm{b}}=k \mp \frac{1}{2}} U_{i, j, k_{\mathrm{b}}} \frac{ \pm T[i, j, k \mp 1, n] \pm T[i, j, k, n]}{2 \Delta x_{i, j, k} \mathrm{~b}} \\
+\frac{P_{\mathrm{HVAC}}[i, j, k, n]+e[i, j, k, n]}{\rho c_{\mathrm{p}}} \\
\frac{T[i, j, k, n+1]-T[i, j, k, n]}{\Delta t}= \\
\sum_{i_{\mathrm{b}}=i \pm \frac{1}{2}} D_{i_{\mathrm{b}}, j, k} \frac{T[i \pm 1, j, k, n]-T[i, j, k, n]}{\left(\Delta x_{i_{\mathrm{b}}, j, k}\right)^{2}} \\
+\sum_{j_{\mathrm{b}}=j \pm \frac{1}{2}} D_{i, j_{\mathrm{b}}, k} \frac{T[i, j \pm 1, k, n]-T[i, j, k, n]}{\left(\Delta x_{i, j_{\mathrm{b}}, k}\right)^{2}} \\
+\frac{P_{\mathrm{HVAC}}[i, j, k, n]+e[i, j, k, n]}{\rho c_{\mathrm{p}}}(\text { otherwise })
\end{array}
$$

ここで，インデックス $i, j, k, n$ はそれぞれ位置 $x, y, z$ および 時刻 $t$ に対応する.（15）式および（16）式の右辺第 1 項およ び第 2 項は室内 $x-y$ 平面における有効熱拡散を表わし，(15) 式の右辺第 3 項はアトリウム内 $z$ 軸方向の移流を表わす。ま 
た，下付き添字を有するパラメータ $U$ および $D$ は各枝にお ける有効流速 $U_{z}$ および有効熱拡散係数 $D_{\mathrm{e}}$ を, $\Delta x$ は空間刻 みまたは面積・境界長比 $\left|A_{\mathrm{c}}\right| /\left|\partial A_{\mathrm{c} x}\right|$ および $\left|A_{\mathrm{c}}\right| /\left|\partial A_{\mathrm{c} z}\right|$ を 表わす。（15）式が移流拡散方程式の形をしているのは，ノー ド $[i, j] \in\{2,3,4,5\} \times\{2\}$ に対応する領域が $S_{\mathrm{atr}}, S_{\mathrm{ofc} 4}$ お よび $S_{\text {ofc5 }}$ の部分集合を含むためである。すなわち，(15) 式 の解は，(12）式の解と（13）式または（14）式の解を当該領 域で空間平均したものに相当する。なお，(15) 式では， $\partial A_{\mathrm{c} z}$ に相当する枝での温度 $T$ を両端ノードの平均とすることによ り右辺第 3 項を表わした。ささらに，室内およびアトリウム内 の空調機の給気風量を参考に， $x$ 軸方向の移流成分を同方向 の有効熱拡散成分（(15）式の右辺第 1 項）と比べて值が小さ いとして無視した.

最後に，(15）式の移流項が（12）式の移流項の妥当な離散 化表現かどうか確認する. 当該移流項のクーラン数 $N_{\mathrm{c}}{ }^{14)}$ は つぎのように表わされる。

$$
N_{\mathrm{c}}:=U \frac{\Delta t}{\Delta x} \simeq 0.1 \mathrm{~m} / \mathrm{s} \times \frac{1 \mathrm{~min}}{21 \mathrm{~m}}=0.29
$$

ここで，Uの代表值として $0.1 \mathrm{~m} / \mathrm{s}$ を用いた（詳細は 5.3 節 の同定結果を参照). クーラン数 $N_{\mathrm{c}}$ が 1 以下であることか ら，文献 14）より離散化スキーム（15）の移流項は数值的に 安定であり，本移流項は（12）式の移流項の妥当な離散化表 現と考えられる.

\section{2 パラメータ算出法}

本節では，KMDを用いた有効流速の算出法を説明する。 第 1 部と同様に,ノード $[i, j, k]$ のアトリウム温度 $T$ に対応 する $\mathrm{KM} \boldsymbol{V}_{m}^{\mathrm{I}}$ の成分を $v_{m}[i, j, k]$, 熱入力 $P_{\mathrm{HVAC}}$ に対応す る $\boldsymbol{V}_{m}^{\mathrm{H}}$ の成分を $u_{m}[i, j, k]$ とおき，各 $\mathrm{KM}$ の応答に対して （15）式および（16）式が成立すると考える。ささらにKMの 固有周期に対応する成分が空調以外の熱源に由来しないとし, 外力 $e$ を無視する（室内熱ダイナミクスの熱移動への寄与に 関しては後述)。以上より，(15）式および（16）式において, $T$ および $P_{\mathrm{HVAC}}$ を $\tilde{\lambda}_{m}^{n} v_{m}$ および $\tilde{\lambda}_{m}^{n} u_{m}$ に置き換え両辺を $\tilde{\lambda}_{m}^{n}$ で除すると次式を得る (複合同順).

$$
\begin{aligned}
\nu_{m} v_{m}= & \sum_{i_{\mathrm{b}}=i \pm \frac{1}{2}} D_{i_{\mathrm{b}}, j, k} \frac{v_{m}[i \pm 1]-v_{m}}{\left(\Delta x_{i_{\mathrm{b}}, j, k}\right)^{2}} \\
& +\sum_{j_{\mathrm{b}}=j \pm \frac{1}{2}} D_{i, j_{\mathrm{b}}, k} \frac{v_{m}[j \pm 1]-v_{m}}{\left(\Delta x_{i, j_{\mathrm{b}}, k}\right)^{2}} \\
& +\sum_{k_{\mathrm{b}}=k \mp \frac{1}{2}} U_{i, j, k_{\mathrm{b}}} \frac{ \pm v_{m}[k \mp 1] \pm v_{m}}{2 \Delta x_{i, j, k_{\mathrm{b}}}} \\
& +u_{m}([i, j] \in\{2,3,4,5\} \times\{2\}) \\
\nu_{m} v_{m}= & \sum_{i_{\mathrm{b}}=i \pm \frac{1}{2}} D_{i_{\mathrm{b}}, j, k} \frac{v_{m}[i \pm 1]-v_{m}}{\left(\Delta x_{i_{\mathrm{b}}, j, k}\right)^{2}} \\
& +\sum_{j_{\mathrm{b}}=j \pm \frac{1}{2}} D_{i, j_{\mathrm{b}}, k} \frac{v_{m}[j \pm 1]-v_{m}}{\left(\Delta x_{i, j_{\mathrm{b}}, k}\right)^{2}} \\
& +u_{m}(\text { otherwise })
\end{aligned}
$$

ここで, $\nu_{m}:=\ln \left[\tilde{\lambda}_{m}\right] / \Delta t$ は $m$ 次 $\mathrm{KM}$ の角周波数である. 変数 $u_{m}$ および $v_{m}$ のインデックスの内 $i, j, k$ と一致するも のは省略した．また， $i=1,6, j=1,2$ および $k=1,2$ で の境界条件はノイマン型とし， $v_{m}$ の差分を 0 とした。本条 件は，アトリウム外部からの熱入力が零であることに相当し， 外気温度および日射量データ中に固有周期 $T_{16}=3.999 \mathrm{~h}$ に 対応する成分が含まれていないことによる。（18）式および （19）式を $U$ および $D_{\mathrm{e}}$ について解くことで移流特性を同定 する.

さらに，物理的に妥当な解を探すための拘束条件を考える. 室内において隣り合う枝同士は同一の VAV から給気の影響 を受けていることから，枝 $\left[i, j_{\mathrm{b}}, k\right] に お け る D_{\mathrm{e}}$ を次式のよ うな加重平均で与える。

$$
\begin{aligned}
& D_{i, j+1 / 2}=\frac{\Delta x_{i+1 / 2, j} D_{i+1 / 2, j}+\Delta x_{i-1 / 2, j} D_{i-1 / 2, j}}{2\left(\Delta x_{i+1 / 2, j}+\Delta x_{i-1 / 2, j}\right)} \\
& +\frac{\Delta x_{i+1 / 2, j+1} D_{i+1 / 2, j+1}+\Delta x_{i-1 / 2, j+1} D_{i-1 / 2, j+1}}{2\left(\Delta x_{i+1 / 2, j+1}+\Delta x_{i-1 / 2, j+1}\right)}
\end{aligned}
$$

ただし添字 $k$ は省略した。（20）式の右辺第 1 項はノード $[i, j]$ での有効拡散係数を隣り合う枝での值の平均值として表わし たものである.第 2 項も，ノード $[i, j+1]$ での有効拡散係 数を同様に表わしたものである。これを平均することで，枝 $[i, j+1 / 2]$ での有效拡散係数とした. 以上の 1 次方程式 (18), （19）拈よび（20）を連立して解くことで $U$ および $D_{\mathrm{e}}$ を算 出する。

最後に, 上記手法と一般的なフーリ工解析に基づく手法と の違いについて補足する．対象とする力学系が線形である場 合は，古典的なフーリ工解析を用いることで本論文と同様の パラメー夕同定を行なうことが可能である．本論文の場合は， 対象とする移流方程式（12）抢よび拡散方程式（13），(14） は線形であるものの, 熱入力 $P$ は方程式の従属変数である温 度 $T$ に関する非線形特性を有する。これは, 熱入力 $P$ の決定 に計測された温度 $T$ がフィードバック信号として用いられて おり，かつこの $P$ の決定過程に空調機動作の非線形特性（飽 和特性，オンオフ特性など）が含まれるためである ${ }^{15)}$. 上記 の非線形性を考慮すると解析対象の移流方程式 (12) および 拡散方程式（13），(14）は非線形となるため，フーリエ変換 の正規直交系を用いてデー夕を単一周期でかつ非干渉なモー ドへ分解することは困難と考えられる。一方，KMD に基づ く提案手法では，上記の非線形性を考慮した上で単一周期で 振動するモードダイナミクスの数理モデル（18）および (19) を導くことができる。

\section{3 結果および考察}

5.2 節で述べた方法で有効流速 $U$ を算出する．算出には 3 章で述べた代表的な KM $\tilde{\boldsymbol{V}}_{16}$ を用いた. 固有周期 $T_{16}=$ $3.999 \mathrm{~h}$ は固体構造を介した熱移動の時定数よりもはるか に小さい. また，外気温中に対応する周期成分が含まれて いないことから，外力 $e$ の影響は排除できる。（20）式は， $[i, j, k] \in\{1, \ldots, 6\} \times\{1\} \times\{1,2\}$ の 12 点で用いた.なお, 


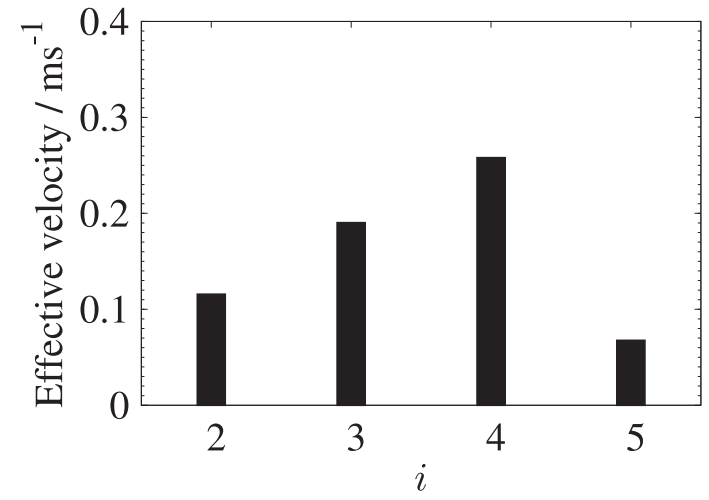

Fig. 15 Calculated velocity at $[i, 2,3 / 2](i=2, \ldots, 5)$

5.2 節の定式化では $U$ を一意に求めることができなかったた め, 求解には擬似逆行列を用いた。

Fig. 15 に各デー夕に対する高さ方向の枝 $[i, 2,3 / 2] （ i=$ $2, \ldots, 5 ） に$ に打る有効流速 $U$ の算出結果を示す．ただし，5 階から 4 階への向きを正としている，算出値はいずれの位置 においても $0.1 \mathrm{~m} / \mathrm{s}$ から $1 \mathrm{~m} / \mathrm{s}$ のオーダとなっている. 空調 機 PU1 㧍よびPU2 の給気風量から概算される速度は $3 \mathrm{~m} / \mathrm{s}$ であり算出值とオーダが近く，これは対象のアトリウムでは 空調給気に起因する低波数成分 $\boldsymbol{u}_{\mathrm{L}}$ による寄与が支配的であ ることを示している，また，すべての位置で有効流速の值が 正であり, 5 階から 4 階への空間平均的な流れが存在している ことがわかる。これは，デー夕を取得した時期のアトリウム 内では空調が泠房運転でかつ給気方向が下向きであり（2 章を 参照），下降気流が支配的になる事実を反映した結果である。 つぎにUの空間依存性について検討する．Fig. 15 を見る と, $U$ は $i=4$ で大きい值となっている。これは対象アトリ ウムの構造に起因していると考えられる。 $i=4$ の位置には ほかの位置と異なり階段があり，上の階と天井に仕切られる ことなく接続されている。このため，ほかの位置と異なり上 階からの成分が重畳し下降気流が卓越し，算出結果はこれを 反映したものと考えられる。

以上より，実測データの KMD 結果を用いることで，アト リウムを介した移流による部屋間熱移動をモデル化すること ができた。

\section{6. おわりに}

本論文ならびに第 1 部となる先行論文 ${ }^{7)}$ の目的は，ビル内 アトリウムに拈ける熱移動ダイナミクスのモデル化を行なう ことにあった。この第 2 部では，まず，アトリウム内に打い て大スケール流速場が支配的となる場合を対象に，部屋間の 熱移動を有効熱拡散項を用いてモデル化した。つぎに，それ らの数理モデルを離散化し，実測データより KMD によって 抽出した支配的な時空間応答を考慮することで熱移動に寄与 するパラメータを算出することを提案した．算出した特性は 対象とした流速場およびビル内の構造を反映したものであり， 提案方法の妥当性が確かめることができた。第 1 部の結果と
合わせると，熱移動ダイナミクスを表現する数理モデルのパ ラメータを実測データの KMD に基づき同定することで，実 測データからアトリウム内の流速場の構造を把握することが 可能となり，モデル化の対象となるビルを問わず熱移動の定 量的な特性評価が可能であることが示された。

最後に，提案したモデル化の適用結果はいずれも空調機の 運転状態や建物構造を反映したものであった。よって，本モ デル化は空調システムの設計段階においてアトリウム内の熱 ダイナミクスの空調運用への影響を把握する上で有用である. 特に, 第 1 部と第 2 部のそれぞれのモデル化手法の適用結果 を比較することにより，アトリウム内流速場の構造を空間ス ケールも含めた形で把握することができ，空調システムの性 能評価につながるものと考えられる。ささに，CFD 解析を用 いないため本モデル化の計算負荷は小さく，実時間での空調 制御および異常検知への応用が期待でき, 今後の課題として 挙げられる.

謝辞 Fig. 1, Fig. 4 の写真を含む, 実建物に関するデータ をご提供いただくとともに，本論文の解析についてご議論い ただきました綛田長生様，西口純也様，古賀圭様（アズビル 株式会社）に心より感謝申し上げます。なお，本研究の一部 は JST，CREST のサポートの下で行なわれた。

\section{参 考 文 献}

1) A.I. Dounis and C. Caraiscos: Advanced Control Systems Engineering for Energy and Comfort Management in a Building Environment-A Review, Renewable and Sustainable Energy Reviews, 13-6, 1246/1261 (2009)

2）綛田，平田，瀬川：業務用建物・工場における省エネルギー技 術動向，システム/制御/情報，55-6, 227/233 (2011)

3) Z. Ren and J. Stewart: Simulating Air Flow and Temperature Distribution inside Buildings Using a Modified Version of COMIS with Sub-zonal Divisions, Energy and Buildings, 35-3, 257/271 (2003)

4) W. Zhang, K. Hiyama, S. Kato and Y. Ishida: Building Energy Simulation Considering Spatial Temperature Distribution for Nonuniform Indoor Environment, Building and Environment, 63, 89/96 (2013)

5）大澤, 原, 古賀, 本田, 綛田：時空間マルチスケールモデリン グによる室内空調の最適制御，計測自動制御学会制御部門大会 予稿集，13,8F3/5 (2013)

6) J.L.M. Hensen and R. Lamberts (eds.): Building Performance Simulation for Design and Operation, Spon Press (2011)

7）河野, 薄, 林田, 引原：ビル内アトリウムの熱移動モデリング へのクープマンモード分解の適用-I一小スケール流速場による 有効熱拡散, 計測自動制御学会論文集, 53-2, 123/133 (2017)

8) I. Mezić: Spectral Properties of Dynamical Systems, Model Reduction and Decompositions, Nonlinear Dynamics, 41-1, 309/325 (2005)

9) C.W. Rowley, I. Mezić, S. Bagheri, P. Schlatter and D.S. Henningson: Spectral Analysis of Nonlinear Flows, Journal of Fluid Mechanics, 641, 115/127 (2009)

10) J.R. Schreiner (ed.): ASHRAE Handbook: Fundamentals, American Society of Heating, Refrigerating and Airconditioning Engineers (1985)

11) M. Avellaneda and A.J. Majda: An Integral Representation and Bounds on the Effective Diffusivity in Passive Advection by Laminar and Turbulent Flows, Communica- 
tions in Mathematical Physics, 138-2, 339/391 (1991)

12) A. Fannjiang and G. Papanicolaou: Convection Enhanced Diffusion for Periodic Flows, SIAM Journal on Applied Mathematics, 54-2, 333/408 (1994)

13) C.W. Hirt and B.D. Nichols: Volume of Fluid (VOF) Method for the Dynamics of Free Boundaries, Journal of Computational Physics, 39-1, 201/225 (1981)

14）藤井孝藏：流体力学の数值計算法, 東京大学出版会 (1994)

15）高橋隆勇：実用 空調設備の自動制御，オーム社 (2003)

16) Y. Susuki and I. Mezić: Nonlinear Koopman Modes and Coherency Identification of Coupled Swing Dynamics, IEEE Transactions on Power Systems, 26-4，1894/1904 (2011)

\section{《付録》}

\section{A. 温度データの周波数スペクトル}

本付録では， 3 章で解析対象とした温度デー夕 $\boldsymbol{T}[n] \in$ $\mathbb{R}^{24}(n=0, \ldots, 540)$ に対するフーリ工変換結果を示す.

Fig. A.1 に, 各階の温度時系列デー夕に離散フーリエ変換 （Discrete Fourier Transform: DFT）を適用することで得ら れた周波数スペクトルを示す，いずれの位置においても，周 期 4.50 時間で周波数スペクトルのピークが確認できる. 周 期 9.00 時間においてもピークが確認できるものの，これは データのサンプリング区間に対応するトレンド成分である. ここで, 代表的なモード対 $\{10,11\}$ および $\{16,17\}$ との関連 について考える. $T_{16}=3.999 \mathrm{~h}$ は上記の周期 4.50 時間と近 く, モード対 $\{16,17\}$ は元データ中の当該周期成分に対応す ると考えられる。なお， $T_{16}$ が上記周期と厳密に一致しない
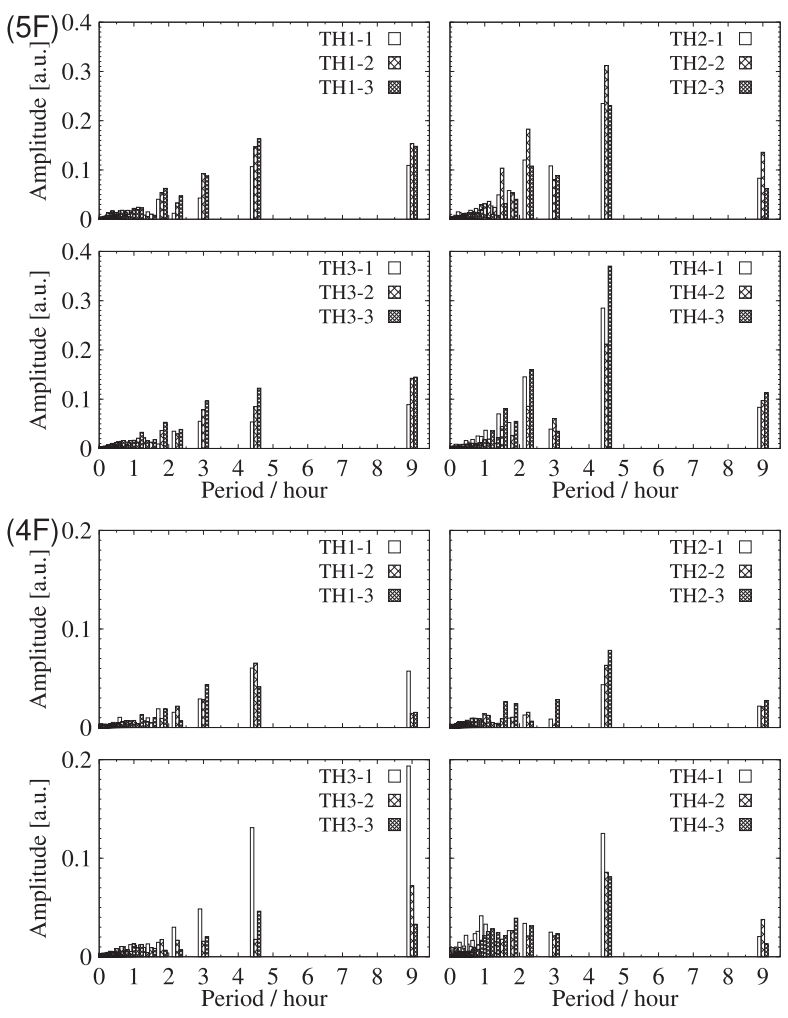

Fig. A.1 Frequency spectrum of time-series data $\boldsymbol{T}[n]$ on inroom temperature
のは，サンプリング区間が短い（すなわち周波数に関する解 像度が低い）ことに加えて，解析対象の時系列データが表わ すダイナミクスが過渡的であることに起因すると考えられる。 文献 16) によると, 力学系の有するアトラクタ上のダイナミ クスに対して，フーリエスペクトルのピーク周波数とクープ マン作用素の離散スペクトルから求まる周波数が一致するこ とが理論的に示される。ここで，本論文で対象とするデー夕 の表わすダイナミクスは過渡的なものであるため，フーリエ スペクトルと KMD から得られる周期の不一致が発生したと 推測される。また， $T_{10}=6.490 \mathrm{~h}$ と近い周期のピークがス ペクトルにおいて確認されないため，モード対 $\{10,11\}$ は元 データ中の振動成分に対応しないと推測される。

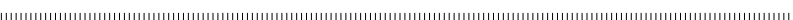

$$
\text { [著 者 紹 介] }
$$

\section{河 野 洋 平}

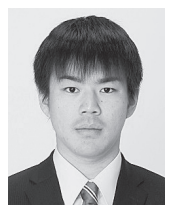

2016 年京都大学大学院電気工学専攻修士課程修 了. 同年（株）日立製作所入社，現在に至る。在 学時はビル内熱ダイナミクスに関する研究に従事. 第 58 回自動制御連合講演会優秀発表賞を受賞.

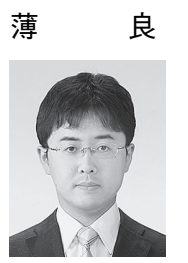

彦（正会員）

2005 年京都大学大学院工学研究科電気工学専攻 博士後期課程修了. 同年京都大学助手, 2007 年助 教, 2011 年講師, 2016 年大阪府立大学准教授と なり現在に至る．2008～2010 年，米国カリフォ ルニア大学サンタバーバラ校機械工学科客員研究 員. 応用非線形ダイナミクス, 電力・エネルギー システム, 制御技術に関する研究に従事. 博士 (工 学)。システム制御情報学会学会賞論文賞 (2009, 2015 年度）などを受賞. システム制御情報学会, 電気学会, 電子情報通信学会, IEEE, SIAM など の会員.

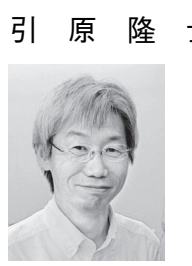

1987 年京都大学大学院工学研究科電気工学専攻 博士後期課程研究指導認定退学. 関西大学を経て, 97 年京都大学助教授, 2001 年同教授となり現在 に至る。この間 93〜94 年米国コーネル大学客員 研究員. パワーエレクトロニクス, 非線形力学の 工学的応用, MEMS の研究, 情報通信 - エネル ギー統合技術の研究開発などに従事. 京都大学工 学博士. システム制御情報学会, 電気学会, 電子 情報通信学会（フェロー），APS，SIAM，IEEE などの会員. 